\title{
Origin and hydrogeochemistry of a shallow flow-through lake on a Pleistocene piedmont, northern Spanish Meseta
}

\author{
Margarita JAMBRINA, " Ildefonso ARMENTEROS, Ángel CORROCHANO, Clemente RECIO \\ Departamento de Geología, Facultad de Ciencias, Universidad de Salamanca, Plaza de los Caidos, s/n 37008, Salamanca, Spain \\ *Corresponding author: margajambrina@usal.es
}

\begin{abstract}
The Cristo lagoon, situated on Neogene deposits in the northern Spanish Meseta, occupies a shallow depression on a Pleistocene piedmont. The development of the lacustrine depression on the piedmont was favoured by the fault network, reinforced by substrate loss by weathering, probably during the late Quaternary. Even during the hot summer season, salinity is low, with concentrations of

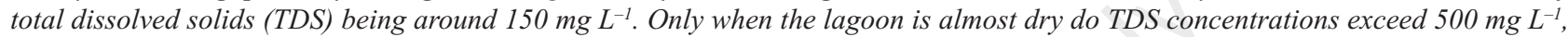
sometimes rising as high as $1700 \mathrm{mg} \mathrm{L^{-1 }}$. When the lake level is high, lake chemistry is dominated by $\mathrm{Na}^{+}, \mathrm{Ca}^{2+}, \mathrm{HCO}_{3}^{-}$and $\mathrm{Cl}^{-}$. $\mathrm{During}$ drier stages, there is a relative increase in $\mathrm{Ca}^{2+}, \mathrm{Mg}^{2+}, \mathrm{Cl}^{-}$, and $\mathrm{SO}_{4}^{2-}$, trending toward a calcium chloride-sulphate brine. Values of pH are above 9 during late spring and summer, resulting primarily from evaporative degassing favoured by the shallow depth of water, and secondarily from photosynthesis by the abundant submerged macrophytes. The infilling deposits, less than $0.5 \mathrm{~m}$ thick, are dark brown, massive, sandy muds consisting of quartz and clays (illite, kaolinite, smectite), all of which are allogenic in origin. The main source of dissolved sulphate was the oxidation of sulphides during weathering of lower Palaeozoic rocks in the catchment area. The ${ }^{13} C$-depleted nature of dissolved inorganic carbon indicates an origin mostly by respiration and oxidation of organic matter. Geomorphology and hydrogeochemistry indicate a flow-through lake dominated essentially by groundwater flows.
\end{abstract}

Key words: Cristo lagoon, geolimnology, hydrogeochemistry, stable isotopes.

Received: May 2012. Accepted: March 2013.

\section{INTRODUCTION}

Wetlands (including ponds and shallow lakes) are ecosystems which provide one of the most important habitats in Iberia for migratory waterbird species. The shallow lakes in Iberia are very complex systems, mainly influenced by geological characteristics, hydrogeological processes and water flow patterns. In addition, they are very sensitive to climatic fluctuations, especially to changes in the rainfall/evaporation balance, and also to biological factors (Committee on Characterization of Wetlands, 1995). Seasonal oscillations in lake level should be reflected in changes in the chemical composition of the water (Quesada et al., 1995). Furthermore, groundwater (GW)-dominated lakes receive dissolved components mainly from discharging GWs, and GW-wetland fluid exchanges are primarily controlled by climate, especially in the arid and semi-arid regions, where the ponds are abundant and these fluctuations are common (Bernáldez, 1989; Rey Benayas, 1990).

Most chemical investigations of ponds and shallow lakes in Central Spain have focused on the occurrence of pollutant chemicals and nutrients, either natural or anthropogenic (Albaiges et al., 1987). Some articles have taken hydrochemistry into account as part of major biological studies (Alonso and Comelles, 1987; Cirujano et al., 1992; Alonso, 1998), but there has been little interest in analysing systematic hydrochemical variations during annual cycles. Lakes in some other high-plain settings differ significantly from Cristo lagoon (CL). Some have a different water source, a higher salinity, and are more acidic (Risarcher et al., 2002). Others are larger and deeper, with a greater variability in the chemical composition of the inflows and the lake water (Li et al., 2008). Still, others are larger and deeper, lie at higher altitudes, are subject to colder climatic conditions, and have higher salinities (Keil et al., 2010).

This study focuses on an unusual wetland - the CL representing a depressed area on a high plain of transient discharge connected to a surficial aquifer (subject to seasonal fluctuations). Its location is characteristic of numerous wetlands on the high plains of Northern-Central Spain, and therefore constitutes a representative example for studying the influence of the GW supply on water composition, and for understanding chemical variations controlled by seasonal changes.

Its geological location aside, it is also worth mentioning the persistence of the CL, which rarely dries out in spite of the semiaridity of the region. This indicates a regional GW supply through the shallow Miocene aquifer, with flow paths sourced in the Variscan siliceous metasediments (Palaeozoic). However, in spite of this relatively long path for its feed-waters, the $\mathrm{CL}$ is characterised 
by minimal mineralisation and alkalinisation during a winter-summer cycle, indicating a flow-through, rather than a local discharge system (Bernáldez et al., 1993; Fernández Aláez et al., 2006). This indicates that the water composition of $\mathrm{CL}$ is controlled by GWs that originate in the Variscan metasediments and interact with the silicic sediments of the Miocene aquifer. This has seldom been addressed in the shallow lakes commonly found on the Variscan (siliceous source areas) domains of the Iberian Peninsula (Fernández Aláez et al., 2006), since most research has been focused on biological and geomorphological features (Alonso and Comelles, 1987; Rey Benayas et al., 1990; Rey Benayas, 1991; Bernáldez et al., 1993; Sanz Donaire and García Rodríguez, 1998).

The present research focuses on the geological origin of the CL, and on a characterisation of the seasonal variability of its hydrogeochemical features, with the aim of establishing a hydrogeochemical model for this flowthrough wetland that would be applicable to wetlands with a similar setting in the central Spanish Meseta. Therefore, this research centres on: i) the hydrochemical composi- tion, seasonal balance and evolution of the CL waters, originating in a siliceous catchment, together with the stable isotope characterisation of CL solutes [dissolved inorganic carbon (DIC), $\mathrm{SO}_{4}{ }^{2-}$; and ii) an integrated sedimentological and morphotectonic analysis, in order to explain the origin and development of the depression occupied by the CL lake.

\section{Geological and environmental setting}

\section{Geology and morphotectonic framework}

Cristo lagoon $\left(40^{\circ} 40^{\prime} 55^{\prime \prime} \mathrm{N}, 6^{\circ} 14^{\prime} 17^{\prime \prime} \mathrm{W}, 845 \mathrm{~m}\right.$ asl) is a shallow lake on a Pleistocene alluvial piedmont at the southern border of the Tertiary Ciudad Rodrigo basin, a markedly elongated depression within the larger Tertiary Duero basin, on the Variscan (Lower Palaeozoic) terrain of the Iberian massif (Fig. 1A-B) (Martín-Serrano et al., 1998).

The piedmont slopes $1 \%$ from $1000 \mathrm{~m}$ asl near the Palaeozoic southern hills of the Peña de Francia (Tamames syncline) down to $840 \mathrm{~m}$ asl in the distal areas

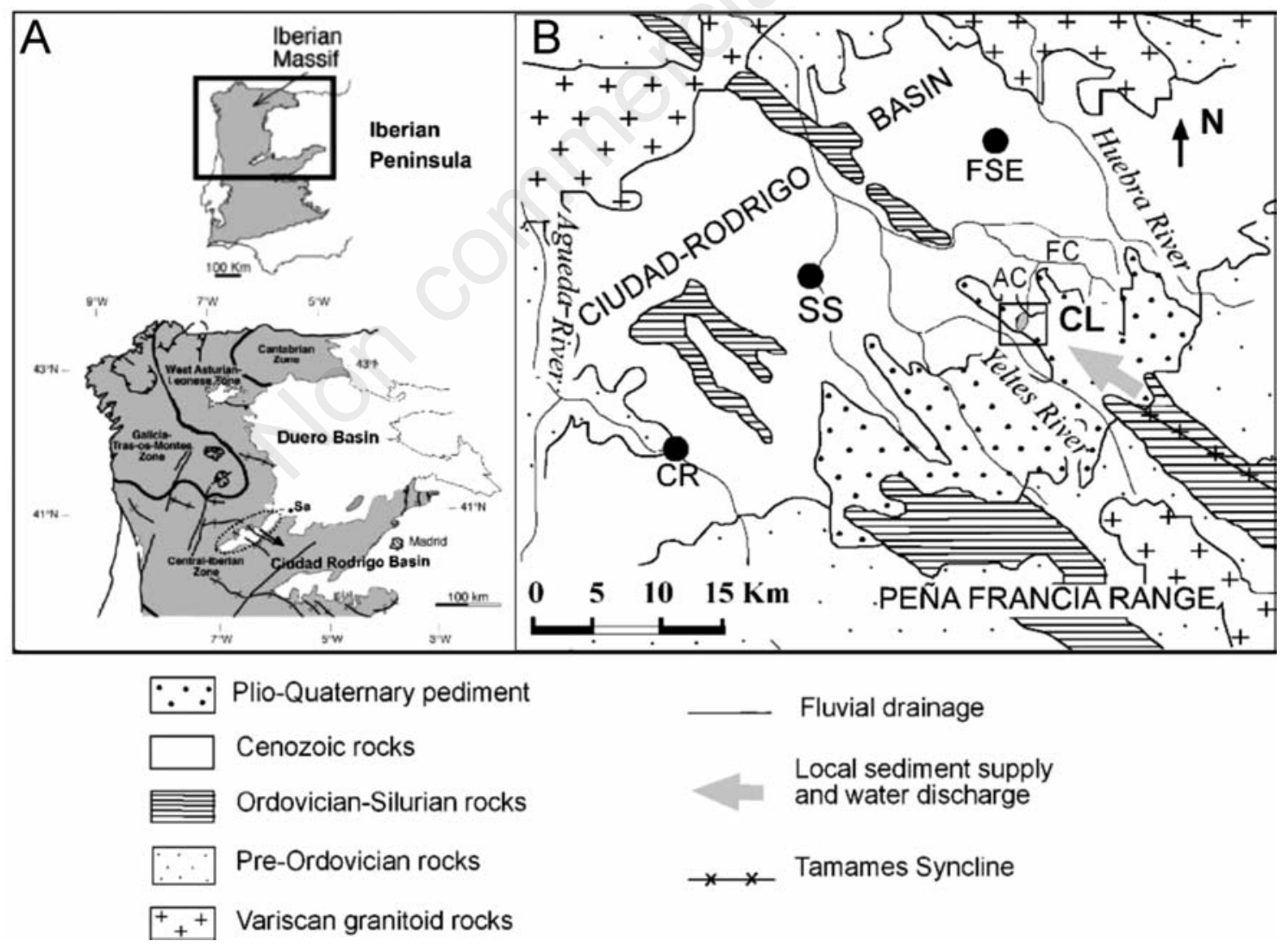

Fig. 1. A) Geological setting of Ciudad Rodrigo basin in the Variscan domains of the Iberian peninsula (after Castro et al., 2003); B) geological sketch of the Ciudad Rodrigo basin where Cristo lagoon is located. The inset corresponds to Fig. 3. SS, Sancti Spiritus; CR, Ciudad Rodrigo; FSE, Fuente de San Esteban; CL, Cristo lagoon; AC, Aguado creek; FC, Fresneda creek. 
where the pond is located, hanging above the Yeltes river, which flows towards north-west on a lower plain $(820 \mathrm{~m}$ asl). The piedmont and lower plain both slope regionally towards north-west, consistent with the main drainage direction (Figs. 1 and 2).

However, locally (in the area surrounding the CL), the piedmont surface on which the pond is situated slopes to- wards north-east, as indicated by the flow direction of Aguado creek, the natural north-easterly outflow of the lagoon, which seldom contains water even in rainy years (Fig. 3). This local slope may be related to the movement of northwest-southeast (NW-SE) faults that were active until recently, such as that controlling the Fresneda creek tract (Fig. 3). On the other hand, the Aguado creek and
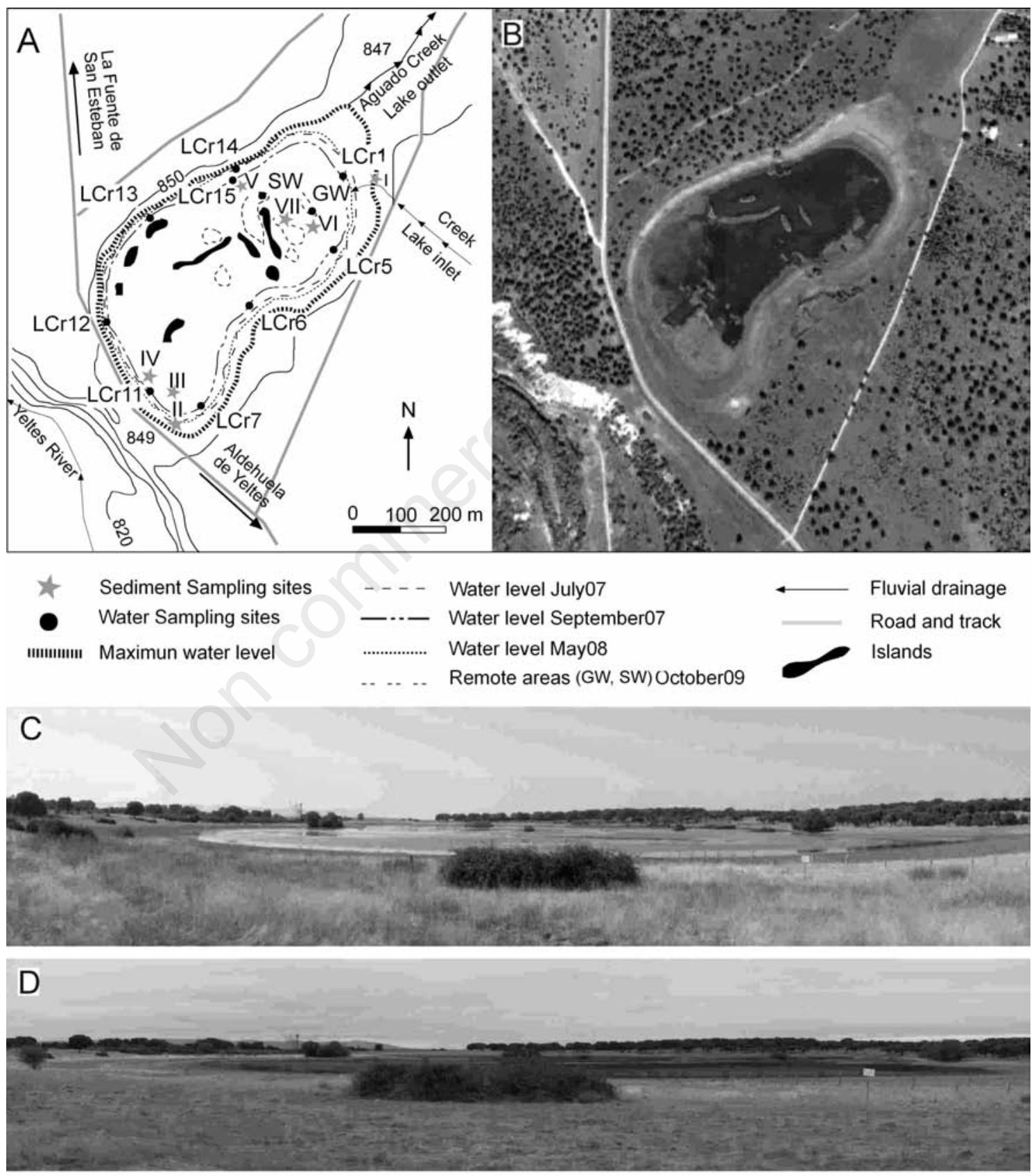

Fig. 2. A) Topographic situation of the Cristo lagoon, with the location of sampling points and the outline of the variation of lake margins; B) aerial view of the area sketched in A; C and D) two different panoramas of Cristo lagoon taken from the same point during high (C) and low (D) water levels. 
the lagoon, situated within the area of its headwaters, are aligned with a southwest-northeast (SW-NE) fault that is highlighted by the existence of a concave scar in the cliff of the right margin slope of the Yeltes river (Figs. 2B and 3) (Martínez Graña et al., 2007).

The piedmont is built on reddish brown, siliciclastic, Miocene gravel deposits, with thinner intercalations of muddy sandstones and mudstones. These deposits lie horizontally. The gravels form sheets ranging from 0.2 to $1 \mathrm{~m}$ in thickness, and are tens of metres wide perpendicular to the palaeocurrent direction, coming from the Tamames Paleozoic syncline to the south-east (Fig. 1B). The current runoff and the general direction of $\mathrm{GW}$ flow follow these ancient directions. Gravel deposits consist of quartzite and, to a lesser extent, quartz clasts (up to $40 \mathrm{~cm}$; mean sizes around $5 \mathrm{~cm}$ ), with an interstitial sandy-clayey matrix. Other than the dominant quartzite clasts (pebbles and cobbles), quartz and, to a lesser extent, schists, the sand-sized fraction mainly consists of quartz, micas and feldspars (orthoclase and albite), whilst the clayey matrix and fine deposits are dominated by the assemblage illite, kaolinite and dioctahedral smectite, in decreasing order. All deposits are impregnated with goethite, resulting in a light brown (5 YR 5/6) to greyish orange (10 YR 7/4) colour. This characteristic weathering profile developed at the top of this Miocene formation is associated with the degradation of the piedmont on the Miocene alluvial fan. This probably occurred during the Pliocene and Quaternary, although new research suggests that this process may still be continuing (Molina et al., 1990; Molina and Cantano, 2002). Two variations of this lithology showing secondary alteration appear in the area surrounding the lagoon: i) the lower bed (2-3 m thick) is the lithological continuation of the underlying less altered Miocene gravelly deposits; it shows a clear colour differentiation consisting of isolated reddish brown patches surrounded by bleached gravels, where the clasts show arenisation; ii) the upper bed (around 1-m thick) consists of brown, quartzitic gravels, disorganised by in situ remobilisation that have largely lost their fine-grained matrix, as a result of eluviation and leaching.

\section{Hydrology}

Regional data on the hydrology of the lagoon area are not available, although the record of lagoon levels from 2007 to 2011, together with popular knowledge in the area, suggests that the $\mathrm{CL}$ is a permanent to semipermanent flow-through steppe wetland characterised by abundant littoral vegetation (Casado and Montes, 1995). The pond is kidney-shaped, around $720 \mathrm{~m}$ in length (SW-NE) and $300 \mathrm{~m}$ in width (NW-SE), and has a maximum depth of $1.8 \mathrm{~m}$ at high water. This shallow lake has no perennial surficial inlet or outlet, but during infrequent rainy years it has a localised ephemeral inlet and an outlet close to the northeastern tip of the lake (Fig. 2). This outlet is con- nected to the Aguado creek, a tributary to the Fresneda creek, which flows into the main water course in the area, the Yeltes river, located in a lower plain below the piedmont where CL is situated (Figs. 2 and 3).

The lagoon water balance is chiefly controlled by the GW dynamics of a surficial, unconfined aquifer that is mainly fed by a catchment area comprising the siliciclastic sediments and metasediments of the Palaeozoic Tamames syncline in the Peña de Francia range (Fig. 1B). The aquifer feeding the pond is hosted within the upper few metres of the underlying Miocene unit, which is made up of conglomerates and muddy sandstones. It has a decreasing hydraulic head from the catchment area (Tamames syncline) towards the northwest that mimics the palaeocurrent directions measured in the Miocene deposits, whose directions were themselves controlled by the Variscan syncline axis (SE-NW) (Fig. 1). The aquifer is recharged both by direct infiltration through the piedmont surface and by lateral GW supply from the Palaeozoic source area in the Peña de Francia range. The pond only shows strong control by direct precipitation on the surrounding areas during very wet years and by direct evaporation during severe droughts. In the driest years, the period of lower lake levels coincides with the beginning of autumn. The relatively stable levels of the lagoon during summertime, in normal precipitation years, suggest that regional GW inflow is the main control of the lagoon level.

\section{Climate and vegetation}

The present climate is continental temperate with a marked dry season during the warm months. According to the Thornthwaite index, it corresponds to a subhumid (nearly semiarid) climate, with prairie vegetation close to the transition to steppe. The monthly mean temperature ranges from 4 (January) to $25^{\circ} \mathrm{C}$ (July). Annual precipitation ranges from 600 to $1000 \mathrm{~mm}$ (Alonso, 1998) with a maximum in autumn (42 $\mathrm{mm}$ in November) and a secondary peak in May. In contrast, the summer months (July to September) are the driest (10 mm in August) (Sánchez y Llorente et al., 1997).

The vegetation of the wide shore of the lake is dominated by Phragmites and Eleocharis palustris, and the lagoon floor is covered by dense stands of aquatic macrophytes (Chara fragifera, Nitella opaca, Myriophyllum, Ceratophyllum, Potamogeton crispus, Potamogeton sp., and Spirogyra) (Alonso, 1998).

\section{METHODS}

Sample cores $(12-30 \mathrm{~cm})$ were taken in July 2007 (under water) and in October 2009 (when the pond was at its lowest level) using a manual corer. Samples, which include both the gravelly substrate and the muddy pond sediments, and their locations are shown in Fig. 2. Cores 
were studied using X-ray diffraction (XRD) for bulk mineralogy, oriented samples of the $<2 \mu \mathrm{m}$ fraction for clay mineral identification and by sedimentological analysis. X-ray powder patterns were obtained using a Bruker D8 Advance diffractometer in the step scan mode, $\mathrm{Cu} \mathrm{K \alpha}$ $\left(\lambda_{1}=1.54060 \AA \hat{x}\right.$ y $\lambda_{2}=1.54439 \AA$ Á) radiation, at a step value of $0.03^{\circ} 2 \theta$, measuring for $1.5 \mathrm{~s}$ at each step. The clay fraction $(<2 \mu \mathrm{m})$ was extracted by decantation after sedimentation and identified by XRD of oriented, air-dried, heated $\left(550^{\circ} \mathrm{C}\right)$, and glycolated samples, by reference to the Joint Committee on Powder Diffraction Standards' database (BRUKER AXS GmbH, Karlsruhe, Germany).

Two selected samples from core VII (characterised by smectite-rich clays) were analysed by inductively coupled plasma-optical mass spectrometry (ICP-OES; Jobin Ivon Ultima II) at the University of Salamanca, Spain.

Hydrochemistry was monitored during the 2007-2008 annual cycle, during the 2009 severe drought (late summer to early autumn), when the lake was almost dry, and at the end of the 2009-2010 wet winter, in order to sample a range of seasonal differences of the physical hydrological parameters and hydrochemistry. Eight points around the perimeter of the pond ( $\mathrm{LCr} 1, \mathrm{LCr} 5, \mathrm{LCr} 6, \mathrm{LCr} 7$, LCr11, LCr12, LCr13 and LCr14; Fig. 2) were sampled in spring (May 2008) and summer (July 2007), and a single point (LCr15) in a deeper zone was sampled in September 2007. At the time of the greatest drought (October 2009), two additional samples were collected from the inner central areas of the pond: surface water (SW), from the surface residual brine, and GW, from an excavated hole $20 \mathrm{~cm}$ below the exposed lake floor. After a wet winter (March 2010), two stations were resampled (LCr5 and LCr6) (Fig. 2). Water samples were collected in clean, high-density polyethylene bottles (1-10 L capacity) that had previously been washed with hydrochloric acid and distilled water, and then thoroughly rinsed with the water to be sampled. All samples were refrigerated at $4^{\circ} \mathrm{C}$ to minimise changes in chemical composition due to bacterial activity before laboratory analysis.

Temperature and pH (Hanna HI 9023 pH meter; Hanna Instruments, Woonsocket, RI, USA), conductivity (CRISON CDTM 523 electronic meter), $\mathrm{Cl}^{-}, \mathrm{SO}_{4}{ }^{2-}$ and phosphates (determined using a PF-11 Macherey-Nagel photometer) were measured at the field site. Once in the
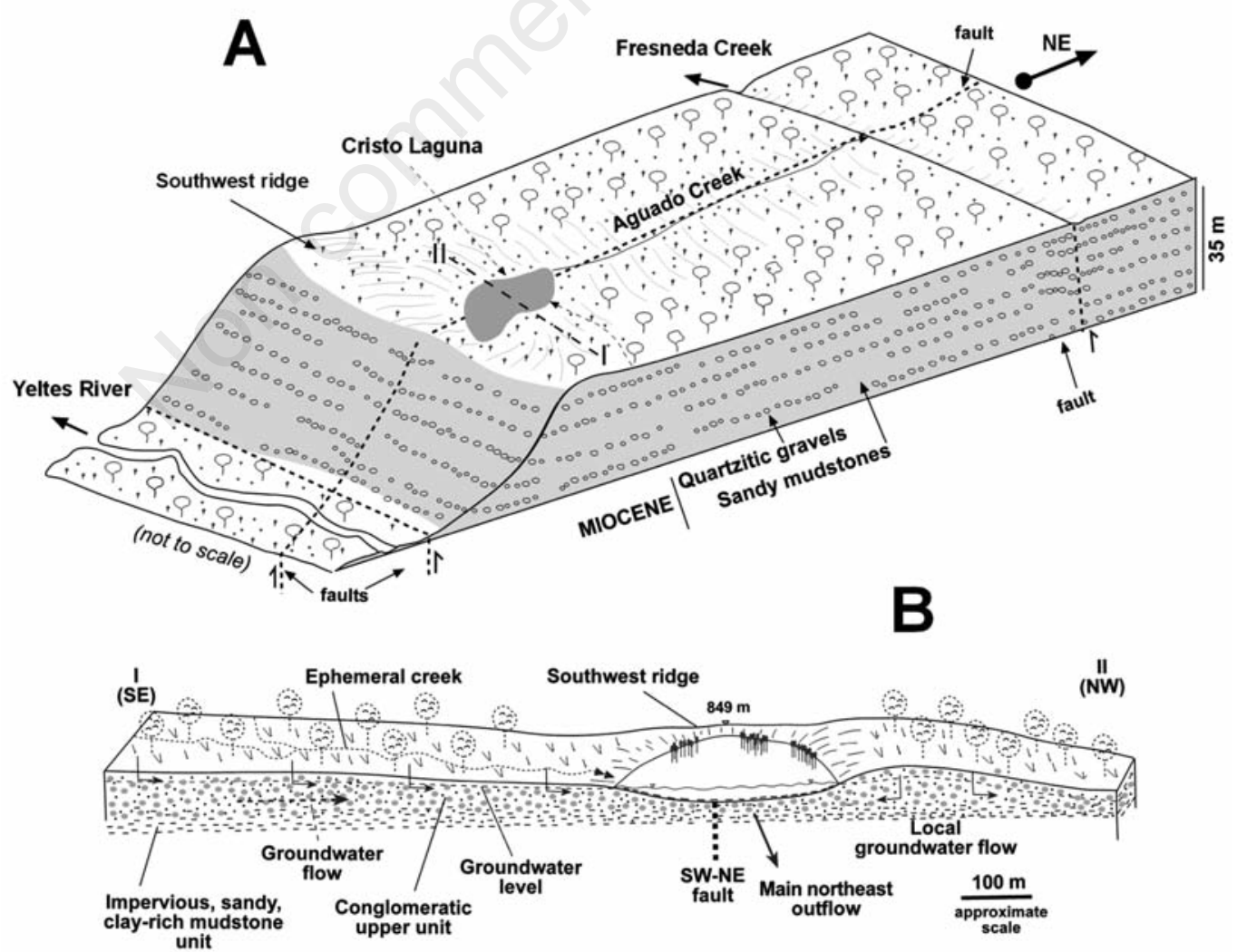

Fig. 3. A) Sketch of the location of the Cristo lagoon on the piedmont developed on the siliciclastic Miocene deposits near the cliff of the Yeltes river; B) conceptual hydrogeological sketch of the Cristo lagoon. 
laboratory, samples were vacuum-filtered through 0.45 $\mu \mathrm{m}$ membrane filters (SUPELCO-Sigma Aldrich, St. Louis, $\mathrm{MO}$, USA; $47 \mathrm{~mm}$ diameter). Alkalinity $\left(\mathrm{CO}_{3}{ }^{2-}\right.$ $+\mathrm{HCO}_{3}{ }^{-}$) was determined in the field on non-acidified samples by acid titration with methyl orange, and is expressed in $\mathrm{mg} \mathrm{L}^{-1}$ as $\mathrm{CaCO}_{3}$. Samples to be analysed for major cations were acidified to $\mathrm{pH}<2$ with $\mathrm{HNO}_{3}$ and $\mathrm{Ca}$, $\mathrm{K}, \mathrm{Mg}, \mathrm{Na}$, and $\mathrm{Si}$ were measured by ICP-OES.

Stable isotope ratios were measured on $\mathrm{SO}_{4}{ }^{2-}$ $\left(\delta^{18} \mathrm{O}_{\mathrm{SMOW}}, \delta^{34} \mathrm{~S}_{\mathrm{CDT}}\right)$ and $\mathrm{HCO}_{3}{ }^{-}\left(\delta^{13} \mathrm{C}_{\mathrm{PDB}}\right)$ dissolved in the water samples. The sulphate was precipitated as $\mathrm{BaSO}_{4}$ by acidification with $\mathrm{HCl}$ to $\mathrm{pH}<2$ and addition of excess $5 \% \mathrm{BaCl}_{2}$. The $\mathrm{BaSO}_{4}$ precipitated was filtered and thoroughly washed with distilled water. $\delta^{34} \mathrm{~S}$ was measured on $\mathrm{SO}_{2}$ produced off-line following the method of Robinson and Kusakabe (1975), with modifications for sulphates by Coleman and Moore (1978). Isotopic ratios were determined on a dedicated dual inlet SIRA-II mass spectrometer at the Stable Isotope Laboratory of Salamanca University, Spain. $\delta^{18} \mathrm{O}$ values were determined on $\mathrm{CO}$ obtained by pyrolysis on a EuroVector elemental analyser, coupled on-line to an Isoprime continuous flow mass spectrometer (Isoprime Ltd., Cheadle, UK). ${ }^{13} \mathrm{C} /{ }^{12} \mathrm{C}$ ratios of $\mathrm{HCO}_{3}{ }^{-}$were measured on $\mathrm{SrCO}_{3}$ precipitated from the previously basified water (to $\mathrm{pH}>9$, using $15 \% \mathrm{NaOH}$ ) by addition of $45 \% \mathrm{SrCl}_{2} . \delta^{13} \mathrm{C}$ was determined on $\mathrm{CO}_{2}$ obtained off-line by reaction with $103 \% \mathrm{H}_{3} \mathrm{PO}_{4}$ (McCrea,
1950; Craig, 1957), measured on a second, dual inlet, SIRA-II mass spectrometer. The isotopic results are expressed in the usual delta notation as per mil deviation from the international primary standard [standard mean ocean wate (SMOW) for $\delta^{18} \mathrm{O}$; canyon diablo troilite (CDT) for $\delta^{34} \mathrm{~S}$, and pee dee belemnite (PDB) for $\left.\delta^{13} \mathrm{C}\right]$. Analytical precision, based on repeated analyses of both in-house and international reference samples (NBS-19; NBS-127), is always better than $\pm 0.2 \%$.

\section{RESULTS}

\section{Mineralogy and sedimentology of the pond deposits}

Sediment recovered from the cores is very thin, up to a maximum of $40 \mathrm{~cm}$ thick in the small, deep, circular depressions of the pond basin. It lies over a substrate of quartzite cobbles, and consists of sandy mud with some partings of muddy sands, coloured dusky brown (5YR 2/1) to brownish black (5YR 2/1), due to the abundance of organic matter. It is a massive, structureless deposit, with abundant bioturbation. Whole rock XRD reveals quartz and clays (illite, kaolinite) as the main inorganic mineral phases; less abundant albite, orthoclase and minor iron oxyhydroxides are present (Tab. 1). The XRD mineralogy of the fine sediment fraction ( $<2$ microns; dried, glycolated and, in some cases, heated samples) consists of, in decreasing order, illite, kaolinite and dioctahedral smectite. Results of

Tab. 1. Mineralogical content.

\begin{tabular}{|c|c|c|c|c|c|c|c|c|c|c|c|c|}
\hline Date & Sediment deposits & Core & $\begin{array}{l}\text { Length core } \\
\qquad(\mathrm{cm})\end{array}$ & $\begin{array}{l}\text { Length } \\
\text { sampling } \\
(\mathrm{cm})\end{array}$ & Sample & Quartz & Moscovite & $\mathrm{Fd}$ & Gypsum & Kaolinite & Smectite & Illite \\
\hline \multirow[t]{11}{*}{2007} & \multirow[t]{2}{*}{ Substrate sediment } & \multirow[t]{2}{*}{ I } & \multirow[t]{2}{*}{30} & 15 & LCr4 & $\mathrm{xx}$ & $\mathrm{t}$ & $\mathrm{t}$ & - & $\mathrm{t}$ & $\mathrm{t}$ & $\mathrm{t}$ \\
\hline & & & & 25 & LCr3 & $\mathrm{xx}$ & $\mathrm{x}$ & $\mathrm{t}$ & $\mathrm{t}$ & $\mathrm{t}$ & $\mathrm{x}$ & $\mathrm{x}$ \\
\hline & \multirow[t]{2}{*}{ Pond sediment } & \multirow[t]{2}{*}{ II } & \multirow[t]{2}{*}{14} & 4 & 6 & $\mathrm{xx}$ & $\mathrm{x}$ & $\mathrm{t}$ & $\mathrm{t}$ & $\mathrm{t}$ & $\mathrm{t}$ & $\mathrm{t}$ \\
\hline & & & & 8 & 5 & $\mathrm{xx}$ & $\mathrm{x}$ & $\mathrm{t}$ & - & $\mathrm{t}$ & $\mathrm{t}$ & $\mathrm{x}$ \\
\hline & \multirow[t]{2}{*}{ Pond sediment } & \multirow[t]{2}{*}{ III } & \multirow[t]{2}{*}{11} & 4 & 8 & $\mathrm{xx}$ & $\mathrm{x}$ & $\mathrm{t}$ & - & $\mathrm{x}$ & $\mathrm{x}$ & $\mathrm{x}$ \\
\hline & & & & 8 & 7 & $\mathrm{xx}$ & $\mathrm{x}$ & $\mathrm{x}$ & $\mathrm{t}$ & $\mathrm{x}$ & $\mathrm{x}$ & $\mathrm{x}$ \\
\hline & \multirow[t]{4}{*}{ Pond sediment } & \multirow[t]{4}{*}{ IV } & \multirow[t]{4}{*}{40} & 5 & 4 & $\mathrm{xx}$ & $\mathrm{x}$ & $\mathrm{x}$ & $\mathrm{t}$ & $\mathrm{t}$ & $\mathrm{t}$ & $\mathrm{x}$ \\
\hline & & & & 15 & 3 & $\mathrm{xx}$ & $\mathrm{x}$ & $\mathrm{x}$ & $\mathrm{t}$ & $\mathrm{x}$ & $\mathrm{t}$ & $\mathrm{x}$ \\
\hline & & & & 25 & 2 & $\mathrm{xx}$ & $\mathrm{x}$ & $\mathrm{x}$ & - & $\mathrm{t}$ & $\mathrm{t}$ & $\mathrm{x}$ \\
\hline & & & & 35 & 1 & $\mathrm{xx}$ & $\mathrm{x}$ & $\mathrm{t}$ & - & $\mathrm{t}$ & $\mathrm{t}$ & $\mathrm{x}$ \\
\hline & Substrate sediment & V & Bulk-sediment & Bulk-sediment & LCr16 & $\mathrm{xx}$ & $\mathrm{x}$ & $\mathrm{x}$ & $\mathrm{t}$ & $\mathrm{t}$ & $\mathrm{x}$ & $\mathrm{x}$ \\
\hline \multirow[t]{9}{*}{2009} & \multirow[t]{4}{*}{ Pond sediment } & \multirow[t]{4}{*}{ VI } & \multirow[t]{4}{*}{12} & 2 & SLC1At & $\mathrm{xx}$ & $\mathrm{x}$ & $\mathrm{x}$ & - & $\mathrm{t}$ & $\mathrm{x}$ & $\mathrm{x}$ \\
\hline & & & & 4 & SLC1Am & $\mathrm{xx}$ & $\mathrm{x}$ & $\mathrm{x}$ & - & $\mathrm{t}$ & $\mathrm{x}$ & $\mathrm{x}$ \\
\hline & & & & 8 & SLC1Bt & $\mathrm{xx}$ & $\mathrm{x}$ & $\mathrm{t}$ & $\mathrm{t}$ & $\mathrm{x}$ & $\mathrm{t}$ & $\mathrm{x}$ \\
\hline & & & & 10 & SLC1Bm & $\mathrm{xx}$ & $\mathrm{x}$ & $\mathrm{x}$ & - & $\mathrm{t}$ & $\mathrm{x}$ & $\mathrm{x}$ \\
\hline & \multirow[t]{5}{*}{ Pond sediment } & \multirow[t]{5}{*}{ VII } & \multirow[t]{5}{*}{26} & 3 & SLC2At & $\mathrm{xx}$ & $\mathrm{x}$ & $\mathrm{t}$ & - & $\mathrm{t}$ & $\mathrm{t}$ & $\mathrm{x}$ \\
\hline & & & & 8 & SLC2Abt & $\mathrm{xx}$ & $\mathrm{x}$ & $\mathrm{t}$ & - & $\mathrm{t}$ & $\mathrm{t}$ & $\mathrm{t}$ \\
\hline & & & & 13 & SLC2Abm & $\mathrm{xx}$ & $\mathrm{x}$ & $\mathrm{x}$ & - & $\mathrm{t}$ & $\mathrm{t}$ & $\mathrm{x}$ \\
\hline & & & & 18 & SLC2Bt & $\mathrm{xx}$ & $\mathrm{x}$ & $\mathrm{x}$ & - & $\mathrm{x}$ & $\mathrm{t}$ & $\mathrm{x}$ \\
\hline & & & & 23 & SLC2Bm & $\mathrm{xx}$ & $\mathrm{x}$ & $\mathrm{t}$ & - & $\mathrm{t}$ & - & $\mathrm{x}$ \\
\hline
\end{tabular}

$F d$, feldspar; $x x$, abundant; $t$, trace; -, not detected; $x$, present. 
the analyses of two smectite-rich samples (core VI) indicate a typical composition of aluminous 2:1 smectite (Deer et al., 1993) (Tab. 2). During the summer 2009 drought, a thin, white crust precipitated out onto the exposed floor of the pond. X-ray diffraction analysis identified gypsum as its main mineral component (Tab. 1). Since the clayey assemblage is similar to that of the Cenozoic substrate, a mostly detrital origin is inferred for these clay minerals.

\section{Hydrogeochemistry}

Field and laboratory analyses are shown in Tab. 3. Water temperatures, which were measured during water sample collection in late spring (May 2008), summer (July and September 2007), mid-autumn (October 2009) and winter (March 2010), range from 10.1 to $27.9^{\circ} \mathrm{C}$. Mid-autumn samples (October 2009) represent an unusually strong drought event. $\mathrm{pH}$ ranged from 5.2 (autumn) and 6.0 (winter) through 8.6 (low water level at the end of summer in a normal hydrological year) to 9.6 (average of summer samples). Total dissolved solid concentrations derived from conductivity measurements vary between 200 and $250 \mu \mathrm{S} \mathrm{cm}^{-1}$ from low to high lake levels. During the October 2009 drought, the highest value $\left(3570 \mu \mathrm{S} \mathrm{cm}^{-1}\right)$ occurred in the GW sample. The lowest value $\left(64 \mu \mathrm{S} \mathrm{cm}^{-1}\right)$ was measured in winter (Tab. 3). Concentrations of the main cations $\left(\mathrm{Mg}^{2+}, \mathrm{Ca}^{2+}, \mathrm{K}^{+}, \mathrm{Na}^{+}\right)$increase significantly from high lake levels to the end-of-summer low level and the October 2009 drought stage. The same is true for the anions. Dissolved silica is low during moderate to high lake levels, but during the October 2009 drought stage it showed a significant increase $\left(22.9 \mathrm{mg} \mathrm{Si} \mathrm{L}^{-1}\right)$. The phosphate concentration is below the detection limit with the photometer used (i.e. $\left.<2 \mathrm{mg} \mathrm{L}^{-1}\right)$, except for SW and GW $\left(4 \mathrm{mg} \mathrm{L}^{-1}\right)$; no determinations were conducted for the winter samples.

The charge balance is nearly at equilibrium for all samples except for the SW sample, where the anion sum

Tab. 2. Chemical analyses of smectite-rich clays.

\begin{tabular}{lcccccccccccc}
\hline Core & Sample & $\mathrm{Al}_{2} \mathrm{O}_{3}(\%)$ & $\mathrm{CaO}(\%)$ & $\mathrm{Fe}_{2} \mathrm{O}_{3}(\%)$ & $\mathrm{K}_{2} \mathrm{O}(\%)$ & $\mathrm{MgO}(\%)$ & $\mathrm{MnO}(\%)$ & $\mathrm{Na}_{2} \mathrm{O}(\%)$ & $\mathrm{P}_{2} \mathrm{O}_{5}(\%)$ & $\mathrm{TiO}_{2}(\%)$ & $\mathrm{SiO}_{2}(\%)$ & $\mathrm{LOI}(\%)$ \\
\hline $\mathrm{VI}$ & $\mathrm{SLC1Am}$ & 21.41 & 0.81 & 9.36 & 2.91 & 1.42 & 0.02 & 1.20 & 0.06 & 0.58 & 49.1 & 11.90 \\
& SLC1At & 19.93 & 1.01 & 9.57 & 2.45 & 1.29 & 0.03 & 1.43 & 0.07 & 0.51 & 47.83 & 16.98 \\
\hline
\end{tabular}

ICP-OES, inductively coupled plasma-optical mass spectrometry.

Tab. 3. Chemical analyses of lake waters.

\begin{tabular}{|c|c|c|c|c|c|c|c|c|c|c|c|c|c|c|c|}
\hline & & Sample & $\mathrm{pH}$ & $\begin{array}{c}\mathrm{T} \\
\left({ }^{\circ} \mathrm{C}\right)\end{array}$ & $\begin{array}{c}\mathrm{EC} \\
\left(\mu \mathrm{S} \mathrm{cm}^{-1}\right)\end{array}$ & $\begin{array}{c}\text { TDS } \\
\left(\mathrm{mg} \mathrm{L}^{-1}\right)\end{array}$ & $\begin{array}{c}\mathrm{Alk} \\
\left(\mathrm{mg} \mathrm{L}^{-1}\right)\end{array}$ & $\begin{array}{c}\mathrm{SO}_{4}^{-2} \\
\left(\mathrm{mg} \mathrm{L}^{-1}\right)\end{array}$ & $\begin{array}{c}\mathrm{Cl}^{-} \\
\left(\mathrm{mg} \mathrm{L}^{-1}\right)\end{array}$ & $\begin{array}{c}\mathrm{PO}_{4}^{-3} \\
\left(\mathrm{mg} \mathrm{L}^{-1}\right)\end{array}$ & $\begin{array}{c}\mathrm{Na}^{+} \\
\left(\mathrm{mg} \mathrm{L}^{-1}\right)\end{array}$ & $\begin{array}{c}\mathrm{K}^{+} \\
\left(\mathrm{mg} \mathrm{L}^{-1}\right)\end{array}$ & $\begin{array}{c}\mathrm{Mg}^{+2} \\
\left(\mathrm{mg} \mathrm{L}^{-1}\right)\end{array}$ & $\begin{array}{c}\mathrm{Ca}^{+2} \\
\left(\mathrm{mg} \mathrm{L}^{-1}\right)\end{array}$ & $\begin{array}{c}\mathrm{Si} \\
\left(\mathrm{mg} \mathrm{L}^{-1}\right)\end{array}$ \\
\hline \multirow[t]{9}{*}{ Summer } & July 2007 & LCR1 & 9.9 & 19.4 & 198 & 127 & 60.0 & 20 & 39 & $<2$ & 22.3 & 14.2 & 8.5 & 19.6 & 0.05 \\
\hline & & LCR5 & 9.6 & 21.8 & 216 & 138 & 60.0 & 20 & 35.4 & $<2$ & 16.1 & 7.1 & 8.4 & 19.3 & 0.05 \\
\hline & & LCR6 & 9.7 & 23.0 & 202 & 129 & 60.0 & 20 & 21.3 & $<2$ & 18.7 & 10.8 & 8.1 & 20.2 & 0.05 \\
\hline & & LCR7 & 9.6 & 23.3 & 223 & 143 & 60.4 & 22 & 85 & $<2$ & 17.6 & 8.1 & 9.2 & 19.7 & 0.05 \\
\hline & & LCR11 & 9.6 & 22.8 & 230 & 147 & 74.6 & 26 & 74.5 & $<2$ & 18.1 & 8.5 & 9.3 & 21 & 0.05 \\
\hline & & LCR12 & 9.8 & 22.0 & 238 & 152 & 65.0 & 27 & 31.9 & $<2$ & 21.0 & 14.5 & 8.8 & 19.8 & 0.05 \\
\hline & & LCR13 & 8.8 & 25.8 & 251 & 161 & 60.0 & 21 & 106.3 & $<2$ & 21.9 & 15.2 & 8.5 & 21.4 & 0.05 \\
\hline & & LCR14 & 9.7 & 24.3 & 226 & 145 & 70.0 & 22 & 77.9 & $<2$ & 18.2 & 11.2 & 7.9 & 18.8 & 0.05 \\
\hline & Sept 2007 & LCR15 & 8.6 & 21.1 & 246 & 157 & 125.0 & 20 & 21.3 & $<2$ & 24.9 & 9.5 & 11.2 & 23.4 & 0.05 \\
\hline \multirow[t]{8}{*}{ Spring } & May 2008 & LCR1 & 9.7 & 20.5 & 243 & 155 & 74.6 & 22 & 39.0 & $<2$ & 21.0 & 6.8 & 9.4 & 19.5 & 0.05 \\
\hline & & LCR5 & 9.5 & 23.0 & 194 & 124 & 65.0 & 20 & 42.5 & $<2$ & 19.3 & 6.0 & 9.0 & 18.8 & 0.05 \\
\hline & & LCR6 & 9.3 & 24.6 & 255 & 163 & 74.6 & 20 & 24.8 & $<2$ & 19.4 & 6.5 & 8.3 & 18.5 & 0.05 \\
\hline & & LCR7 & 8.9 & 26.7 & 230 & 147 & 80.0 & 20 & 88.6 & $<2$ & 20.5 & 7.8 & 7.4 & 18.6 & 0.05 \\
\hline & & LCR11 & 9.2 & 25.4 & 257 & 164 & 85.0 & 21 & 77.9 & $<2$ & 22.7 & 7.2 & 9.7 & 21.7 & 0.05 \\
\hline & & LCR 12 & 10.3 & 24.9 & - & - & 74.6 & 20 & 32.9 & $<2$ & 18.6 & 6.4 & 8.7 & 19.3 & 0.05 \\
\hline & & LCR13 & 9.8 & 24.1 & - & - & 80.0 & 24 & 99.3 & $<2$ & 18.5 & 6.3 & 8.5 & 19.2 & 0.3 \\
\hline & & LCR14 & 10.4 & 24.6 & - & - & 80.0 & 20 & 77.9 & $<2$ & 18.7 & 5.8 & 9.0 & 19.2 & 0.2 \\
\hline \multirow[t]{2}{*}{ Autumn } & Oct 2009 & SW & 6.5 & 22.1 & 1003 & 465 & 182.4 & 384 & 300 & 4 & 43.2 & 16.3 & 35.8 & 113.9 & 11.7 \\
\hline & & GW & 5.2 & 27.9 & 3570 & 1790 & 65.0 & 1385 & 700 & 4 & 147.5 & 62.1 & 171.5 & 530.3 & 22.9 \\
\hline \multirow[t]{2}{*}{ Winter } & March 2010 & $\mathrm{LCr} 5$ & 6.0 & 10.5 & 64 & 32 & 15.0 & 21 & 8.0 & - & 3.6 & 0.3 & 1.8 & 4.3 & 0.5 \\
\hline & & LCr6 & 5.9 & 10.1 & 147 & 74 & 17.5 & 48 & 20 & - & 8.0 & 3.0 & 5.0 & 15.2 & 0.6 \\
\hline
\end{tabular}

T, temperature; EC, electrical conductivity; TDS, total dissolved solids; Alk, alkalinity; Sept, September; Oct, October; SW, surface water; GW, groundwater $20 \mathrm{~cm}$ below the exposed lake floor. 
of milliequivalents is almost twice that of the cations $(20.2$ $\mathrm{meq}_{\mathrm{an}} / 10.8$ meq $_{\mathrm{cat}}=1.9$ ).

In the trilinear molar percent diagram (Hardie and Eugster, 1970; Eugster and Hardie, 1978), the separation of the samples corresponding to low and high lake levels in the years 2007 and 2008, and the separation of the samples taken in the winter of 2010 from those taken during the October 2009 drought, are evident, both for anions and cations (Fig. 4). Samples from the October 2009 drought are significantly enriched in $\mathrm{Ca}^{2+}$ and $\mathrm{SO}_{4}{ }^{2-}$, slightly enriched in $\mathrm{Mg}^{2+}$ and $\mathrm{Cl}^{-}$, and show a relative decrease in $\mathrm{HCO}_{3}{ }^{-}+\mathrm{CO}_{3}{ }^{2-}$. The final, more evolved water reflects a trend towards a calcium chloride-sulphate brine.

Representation of the common system $\mathrm{Ca}-\mathrm{SO}_{4}-\left(\mathrm{HCO}_{3}\right.$ $+\mathrm{CO}_{3}{ }^{2-}$ ) in the Spencer Triangle (Jones and Deocampo, 2003 ) is the simplest way of illustrating the solute evolution of the waters (Fig. 5). It is constructed by placing these three components in equivalents at the vertices of a triangular diagram. Plotting the values for the CL water samples showed that less concentrated and alkaline samples, corresponding to high lake levels, evolved by evaporation to slightly acidic values during the drought stage, when there was a relative decrease in $\mathrm{HCO}_{3}{ }^{-}+\mathrm{CO}_{3}{ }^{2-}$ and a significant increase in $\mathrm{SO}_{4}^{2-}$, consistent with the observed precipitation of gypsum during the October 2009 drought.

\section{Stable isotopes}

Dissolved sulphate $\delta^{34} \mathrm{~S}$ (\%o CDT) and $\delta^{18} \mathrm{O}(\%$ SMOW) results obtained are detailed in Tab. 4. Measured values range from 7.1 to $9.8 \%$ for $\delta^{34} \mathrm{~S}_{\mathrm{SO}_{4}{ }^{2-}}$ and from 5.5

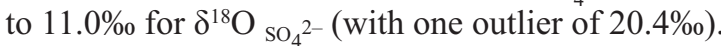

The eight $\delta^{13} \mathrm{C}_{\text {DIC }}$ values measured from the samples taken in July 2007 range from -19.76 to $-24.24 \%$, with an outlier of $-13.92 \%$. More recent analyses during the October 2009 drought (ground water sample) and at the end of the 2010 winter (March 2010) are slightly more negative (Tab. 4).

\section{DISCUSSION}

This section is focused on the three main objectives of this study, namely the hydrochemical characteristics, the stable isotopic characterisation and the origin of the lagoon.

\section{Hydrochemistry}

Discussion of water hydrochemistry is focused mainly on water characteristics during the spring/summer seasons and the inter-season comparison at normal water levels and during the abnormal October 2009 drought. The absence of $\mathrm{CaCO}_{3}$ precipitates and the striking changes of $\mathrm{pH}$ require particular attention.

During the spring and summer stages, the water is slightly oversaturated with respect to calcite, as indicated by the inverse relationship between $\log \left[\mathrm{Ca}^{2+}\right]$ and $\mathrm{P}_{\mathrm{CO} 2}$, which is reflected in the leftward displacement of the equilibrium line in Fig. 6 (Deocampo and Ashley, 1999), although calcite precipitates were never found. It is known

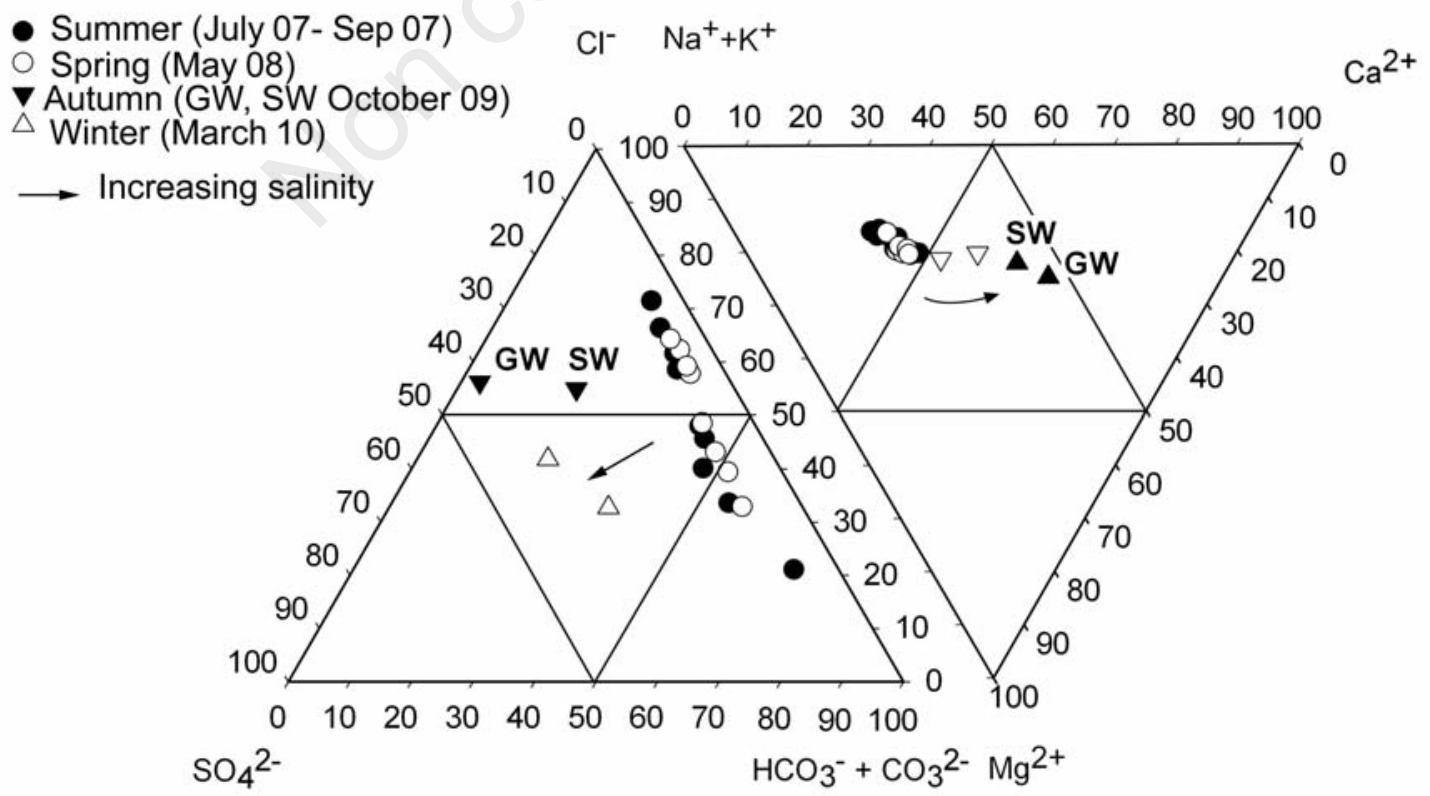

Fig. 4. Composition of the lagoon water in the system $\mathrm{Ca}^{2+}-\mathrm{Mg}^{2+}-\left(\mathrm{Na}^{+}+\mathrm{K}^{+}\right)-\left(\mathrm{HCO}_{3}{ }^{-}+\mathrm{CO}_{3}{ }^{2-}\right)-\mathrm{Cl}^{-}-\mathrm{SO}_{4}{ }^{2-}$ (percent molar composition for anions and cations). 
that organic acids and phosphate inhibit the precipitation of carbonate both in fresh water and sea water (Berner and Morse, 1974). However, in the CL, maximum phosphate concentration attains a value of around $4 \mathrm{ppm}(\approx 0.04$ $\mu \mathrm{mol} \mathrm{L}{ }^{-1}$ ) during the October 2009 drought, which is well below the known limit for inhibition $\left(<1.0 \mu \mathrm{mol} \mathrm{L}^{-1}\right.$; Lebron and Suárez, 1996). On the other hand, the concentration of organic acids in the lagoon during the spring/summer seasons is unknown, although during the drought stage, it is expected that residual organic acids are present in quantities sufficient to inhibit calcite precipitation (even $<10 \mu \mathrm{m} \mathrm{L}^{-1}$ can prevent its precipitation). However, the true influence of phosphates and organic acids on the inhibition of calcite precipitation is unknown.

The enrichment of all ions in the two samples taken during the October 2009 drought results from evaporative concentration, as evidenced by the positive correlation between $\mathrm{Na}^{+}, \mathrm{Ca}^{2+}, \mathrm{Mg}^{2+}$ and $\mathrm{Cl}^{-}$with $\mathrm{SO}_{4}{ }^{2-}$. The lower amount of $\mathrm{SO}_{4}{ }^{2-}$ and $\mathrm{Ca}^{2+}$ in $\mathrm{SW}$ relative to $\mathrm{GW}$ is also observed in all other components, confirming less evaporitic concentration of SW relative to GW. Loss of both ions from solution as gypsum precipitates seems to be minor, since the molar ratio $\mathrm{SW}$ : GW for each ion remains similar (approximately 0.2). The higher concentration in the GW sample is probably related to evaporitic pumping in the capillary zone, the efflorescent gypsum crust being

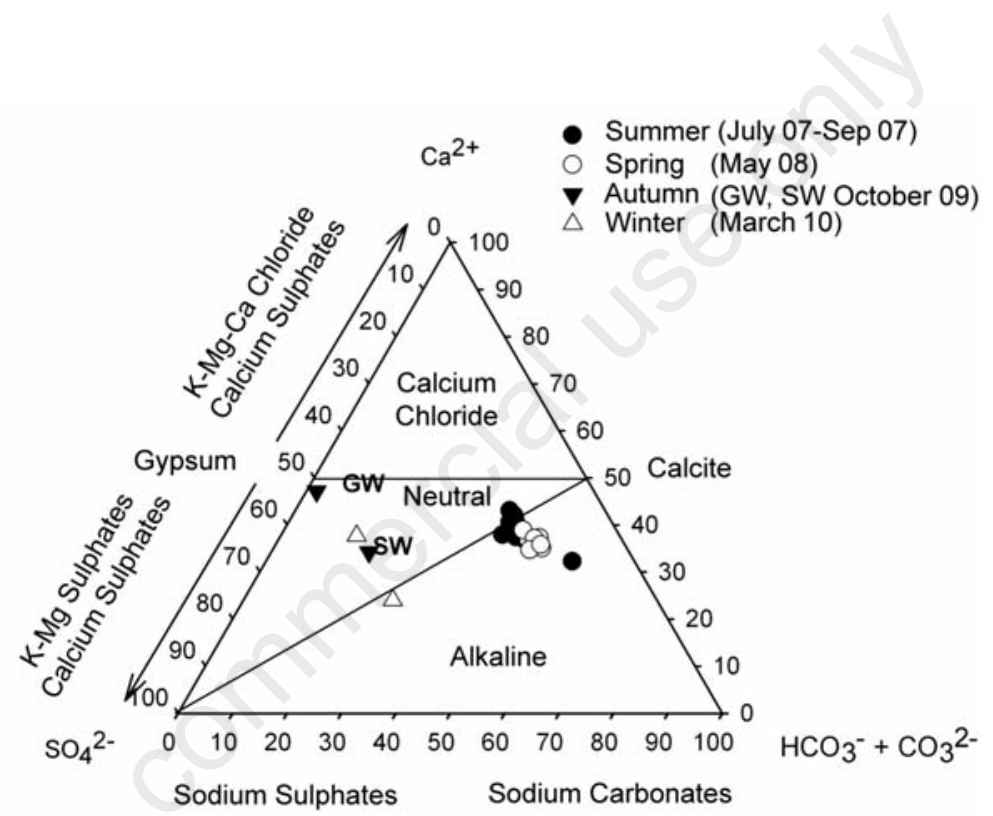

Fig. 5. Plot of the common system $\mathrm{Ca}^{2+}-\mathrm{SO}_{4}{ }^{2-}-\left(\mathrm{HCO}_{3}{ }^{-}+\mathrm{CO}_{3}{ }^{2-}\right)$ in a Spencer triangle. Quantities are expressed in percent milliequivalents $\mathrm{L}^{-1}$ for each vertex component. Note that the October 2009 drought resulted in samples enriched in $\mathrm{SO}_{4}{ }^{2-}$ and $\mathrm{Ca}^{2+}$ and impoverished in carbonate species relative to the rest.

Tab. 4. Isotopic ratios measured in dissolved inorganic carbon and dissolved sulphate.

\begin{tabular}{|c|c|c|c|c|c|}
\hline Season & Period & Sample & $\delta^{13} \mathrm{C}_{\mathrm{DIC}}$ & $\delta^{34} \mathrm{~S}_{\mathrm{SO}_{4}}$ & $\delta^{18} \mathrm{O}_{\mathrm{SO}_{4}}$ \\
\hline Summer & July 2007 & $\begin{array}{c}\text { LCR1 } \\
\text { LCR5 } \\
\text { LCR6 } \\
\text { LCR7 } \\
\text { LCR11 } \\
\text { LCR12 } \\
\text { LCR13 } \\
\text { LCR14 }\end{array}$ & $\begin{array}{l}-19.77 \\
-21.29 \\
-19.76 \\
-13.92 \\
-19.98 \\
-23.76 \\
-24.24 \\
-23.08\end{array}$ & $\begin{array}{c}- \\
9.8 \\
- \\
- \\
- \\
- \\
- \\
-\end{array}$ & $\begin{array}{c}- \\
20.4 \\
- \\
- \\
- \\
- \\
- \\
-\end{array}$ \\
\hline Autumn & Oct 2009 & $\begin{array}{l}\text { SW } \\
\text { GW }\end{array}$ & $\begin{array}{c}- \\
-26.1\end{array}$ & $\begin{array}{l}9.6 \\
7.2\end{array}$ & $\begin{array}{l}11.0 \\
10.9\end{array}$ \\
\hline Winter & March 2010 & $\begin{array}{l}\text { LCr5 } \\
\text { LCr6 }\end{array}$ & $\begin{array}{l}-25.76 \\
-26.41\end{array}$ & $\begin{array}{l}7.1 \\
8.1\end{array}$ & $\begin{array}{l}7.5 \\
5.5\end{array}$ \\
\hline
\end{tabular}

Oct, October; SW, surface water; GW, ground water $20 \mathrm{~cm}$ below exposed lake floor. 
the final product of capillary rising. Binary plots (not shown) between $\mathrm{Cl}^{-}, \mathrm{Na}^{+}, \mathrm{Ca}^{2+}, \mathrm{SO}_{4}{ }^{2-}$ and $\mathrm{HCO}_{3}{ }^{-}$(this latest only in $\mathrm{SW}$ ) show the expected conservative evaporitic enrichment.

The drop in $\mathrm{HCO}_{3}{ }^{-}$for $\mathrm{GW}$, which shows the lowest value of any samples, suggests precipitation of carbonate. However, at $\mathrm{pH}=5.2$ measured for GW, Fig. 6 indicates that a simultaneous increase of $\left[\mathrm{Ca}^{2+}\right]$ and $\mathrm{P}_{\mathrm{CO} 2}$ is possible without calcite precipitation. Thus, under the above conditions, calcite precipitation would require much more $\mathrm{Ca}^{2+}$ than is available (Drever, 1997). The $\mathrm{pH}$ decrease may result from acidification of the pore waters by organic acids and from oxidation of organic matter, which induced an increase in $\mathrm{P}_{\mathrm{CO} 2}$ and therefore greater subsaturation with respect to calcite (Deocampo and Ashley, 1999). Lower $\delta^{13} \mathrm{C}$ values of DIC seem to corroborate the influence of oxidised organic matter. It is known that $\mathrm{pH}$ can fall as a result of the decay of plant matter during evaporation in some saline environments (i.e. Coorong lake, Australia; Hesse, 1990). It should be noted that calcite was never found as a precipitate, at any stage of the $\mathrm{CL}$, which is at odds with the chemical divide (Hardie and

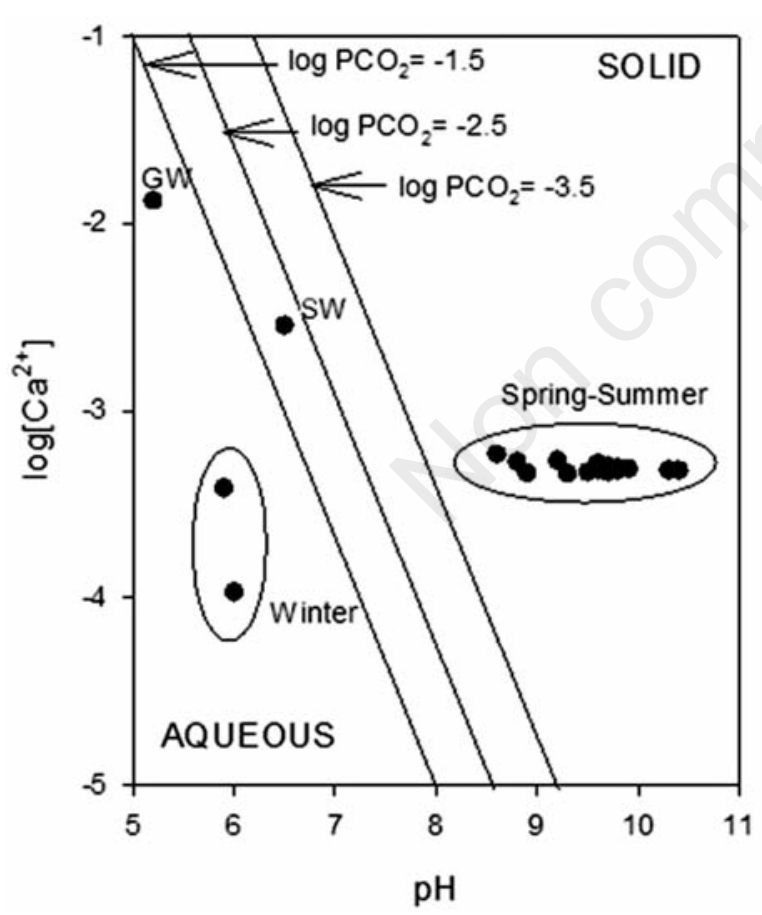

Fig. 6. $\mathrm{pH}-\log \left[\mathrm{Ca}^{2+}\right]$ diagram showing calcite solution/precipitation equilibrium as $\log \mathrm{P}_{\mathrm{CO} 2}$ changes from atmospheric (-3.5) to higher (-2.5 to -1.5$)$ values. As $\mathrm{P}_{\mathrm{CO} 2}$ increases there is a drop in $\mathrm{pH}$, and the equilibrium $\mathrm{Ca}^{2+}{ }_{\max }$ line shifts to the left. Winter samples, as well as surface water and ground water remain undersaturated in calcite (see text for details) (based on Deocampo and Ashley, 1999).
Eugster, 1970), whose general principle requires the precipitation of a calcium carbonate phase before any gypsum can form. As evidenced by cations (Fig. 4), the evaporitic path of waters does not follow a trend toward the $\mathrm{Na}+\mathrm{K}$ pole, but rather reflects a relative enrichment in $\mathrm{Ca}^{2+}$ and $\mathrm{Mg}^{2+}$, which runs counter to the trend in most lakes undergoing evaporitic evolution (Eugster and Hardie, 1978). The mineralogical composition of the lagoon sediment and substrate (Tab. 1) does suggest that this enrichment is due to water-sediment/substrate exchange. Higher $\mathrm{Al}$ content and lower $\mathrm{Mg}$ and $\mathrm{Ca}$ content in the smectite-rich samples from the lake floor sediment (Tabs. 1 and 2) indicate dioctahedral smectites of probable detrital origin, discounting $\mathrm{Ca}-\mathrm{Mg}$ exchange between lagoon water and the sediment. The trend in the anion molar diagram $\left[\left(\mathrm{HCO}^{-}+\mathrm{CO}_{3}{ }^{2-}\right)-\mathrm{Cl}^{-}-\mathrm{SO}_{4}{ }^{2-}\right]$, on the other hand, behaves as expected: waters plot in the $\left(\mathrm{HCO}_{3}{ }^{-}+\mathrm{CO}_{3}{ }^{2-}\right)$ $\mathrm{Cl}^{-}$side at normal to high water levels, and evolve towards the $\mathrm{Cl}-\mathrm{SO}_{4}{ }^{2-}$ axis as a result of evaporation (October 2009 drought). In spite of the evaporitic concentration, the absence of $\mathrm{CaCO}_{3}$ precipitation essentially reflects the subsaturation of waters with respect to calcite: in contrast to increasing values of $\mathrm{pH}$ and $\mathrm{CO}_{3}{ }^{2-}$, normally expected during the evaporitic concentration of dilute waters (Garrels and Mackenzie, 1967), CL behaves differently, which explains why calcite does not precipitate despite an increase in $\mathrm{Ca}^{2+}$ and $\mathrm{Mg}^{2+}$ concentrations.

There are, however, additional issues regarding the change in $\mathrm{pH}$ : the significant drop associated with the October 2009 drought could result from the decay of organic matter and the increase in sulphate during evaporation and ensuing salinity increase (Hesse, 1990). Additionally, during drought stages, $\mathrm{pH}$ is also lowered by the reoxidation of $\mathrm{Fe}^{2+}$ (ferrolysis), resulting in further acidification (Van Ranst and De Coninck, 2002). Calcite subsaturation in $\mathrm{GW}$, in spite of its high $\mathrm{Ca}^{2+}$ content, is explained by the $\mathrm{pH}$ decrease and the $\mathrm{P}_{\mathrm{CO} 2}$ increase (Tab. 3; Fig. 6). Indeed, as the water chemistry evolves by evaporation, $\mathrm{pH}$ decreases and the $\mathrm{HCO}_{3}{ }^{-}+\mathrm{CO}_{3}{ }^{2-}$ contribution to $\sum \mathrm{CO}_{2}$ becomes small, explaining the lack of calcium carbonate precipitation (Given and Wilkinson, 1985). On the other hand, the $\mathrm{pH}$ of relatively high water levels during the spring to summer seasons is about 4 units higher than for the drought stage (from 5.2 to 9.6; Tab. 3), which is mostly caused by the significant removal of $\mathrm{CO}_{2}$ due to holomixis. The highest observed $\mathrm{pH}$ values (up to 9.6) in spring (May 2008) and summer (July 2007) samples coincide with greater development of the aquatic vegetation and higher temperatures, which would have led to an increase in photosynthetic activity and $\mathrm{CO}_{2}$ loss. However, high $\mathrm{pH}$ values also occur during periods of scarce macrophytic vegetation, suggesting that macrophyte photosynthesis is not the principal factor. The two winter samples are plotted in the area of subsaturation due to the lower 
$\left[\mathrm{Ca}^{2+}\right]$ and $\mathrm{pH}$ values (Fig. 6) and the presumed higher $\mathrm{P}_{\mathrm{CO} 2}$ at lower temperatures.

Increase in silica values during the October 2009 drought stage is interpreted to be a consequence of evaporative concentration. However, in spite of this higher concentration, silica and silicate precipitates were not found on the lagoon floor (concentrations did not exceed the solubility of opal).

\section{Stable isotopes}

Sulphate in water can be of anthropogenic origin (industrial wastes, pesticides, fertilisers, animal wastes, etc.) or natural origin. Although the values for ${ }^{34} \mathrm{~S}_{\mathrm{SO}_{4}}{ }^{2-}$ (7.1 to $9.8 \%$ ) and $\delta^{18} \mathrm{O}_{\mathrm{SO} 4}{ }^{2-}(5.5$ to $11.0 \%$ ) are within the range of anthropogenic sources $\left(\delta^{34} \mathrm{~S}=0\right.$ to $+10 \% ; \delta^{18} \mathrm{O}=+5$ to $+15 \%$; Nriagu et al., 1991), this influence can be ruled out, since the area is remote and far from industrial and agricultural spillages, and cattle farming is insignificant. Natural sulphate can be produced by the weathering of Palaeozoic and Tertiary rocks in the recharge area and the surrounding fringe of the lake. No evaporite outcrops are known in the region, and therefore it is expected that the isotope values will not be associated with evaporite weathering. Sulphides, on the other hand, are relatively abundant in the Variscan rocks of the source area in the Tamames syncline (siliciclastic sedimentary and metasedimentary rocks). Oxidation during weathering of sulphides is not known to result in marked fractionation of ${ }^{34} \mathrm{~S} /{ }^{\beta 2} \mathrm{~S}$ ratios (from no fractionation observed in field studies to a maximum average fractionation of $\Delta_{\mathrm{SO}^{2}}{ }^{2-} \mathrm{s}{ }^{2} \approx-5.2 \%$ in high-pH experiments at environmental temperatures; Fry et al., 1988; Toran and Harris, 1989). Regional Lower Palaeozoic rocks average $\delta^{34} \mathrm{~S} \approx+9 \%$ (Recio, unpublished), and as such, are a potentially reasonable source of the sulphur in the dissolved pond sulphate.

$\delta^{18} \mathrm{O}$ values measured in aqueous $\mathrm{SO}_{4}{ }^{2-}$ increase progressively from the ephemeral creek feeding the pond, to high-water sulphate and then to maximum drought samples, suggesting that evaporation is the main mechanism for ${ }^{18} \mathrm{O}$ enrichment (Pierre, 1988).

The $\delta^{13} \mathrm{C}_{\mathrm{DIC}}$ values (Tab. 4) are indicative of a strong biogenic contribution to dissolved C (C3 biota typically have $\delta^{13} \mathrm{C}$ values ranging from -25 to $-28 \%$; Deines, 1980), and the terrestrial detritus derived from $C 3$ plants has a mean value of $\delta^{13} \mathrm{C}=-28 \pm 0.2 \%$ in rivers, although the endogenous organic matter (algae, seston) may vary widely (Finlay and Kendall, 2007). The oxidation of organic matter, either by dissolved oxygen $\left(\mathrm{CH}_{2} \mathrm{O}+\mathrm{O}_{2} \rightarrow\right.$ $\left.\mathrm{CO}_{2}+\mathrm{H}_{2} \mathrm{O}\right)$ or bacterial sulphate reduction $\left(2 \mathrm{CH}_{2} \mathrm{O}+\mathrm{SO}_{4}{ }^{2-}\right.$ $\rightarrow 2 \mathrm{CO}_{2}+\mathrm{S}^{2-}+2 \mathrm{H}_{2} \mathrm{O}$ ), will contribute isotopically light $\mathrm{C}$ to the DIC pool (Atekwana and Krishnamurthy, 1998; Kendall and Doctor, 2003). The dominance of siliciclastic (meta)sediments and the scarcity of carbonates in the catchment area, together with the siliciclastic nature of the
Miocene aquifer feeding the pond, explain the low $\delta^{13} \mathrm{C}$ values of DIC in the lake water, indicating that the $\mathrm{HCO}_{3}{ }_{3}^{-}$ is derived mainly from organic $\mathrm{CO}_{2}$. Higher values of DIC during summertime are probably for the most part the result of photosynthetic processes. This may be related to the greater organic productivity (abundant aquatic plants), consuming the light isotope, and to poor mixing with the rest of the pond. On the other hand, the higher values of the samples taken in the south-eastern margin ( $\mathrm{LCr} 1$, LCr5, LCr6 and LCr7 samples; Fig. 2 and Tab. 4), could be due to its shallower water.

\section{Origin of the lagoon}

Casado and Montes (1995) proposed a man-made origin for the lagoon, but the absence of excavated material, geomorphological features in the surrounding areas, and the morphotectonic considerations detailed below, indicate an alternative natural origin.

Structural control exerted by the two crossing sets of faults with NW-SE and NE(NNE)-SW(SSW) directions has conditioned the drainage on the piedmont and is probably the primary control on the development of the lagoon (Fig. 3).

In addition to this morphotectonic control, a combination of substratum and climatic factors may have also contributed to the evolution of Cristo lagoon. This is indicated by two characteristic features: the first is the elliptical shape, elongated along the NE-SW axis, coinciding with the currently dominant winds in the area, that have either a north-easterly or south-westerly component. However, the southwesterly wind components are dominant all year long (Sánchez y Llorente et al., 1997). It is known that the northern Spanish Meseta was subjected to two phases of aeolian activity after the last glacial stage. The first correlates with the cold, arid Younger Dryas (about 12.5 to $10.2 \mathrm{ky} \mathrm{cal}$. BP) and the most recent occurred during the warm aridity of the Atlantic period (about 6.5 to $8.8 \mathrm{ky} \mathrm{cal}$. BP), as dated by luminescence [thermoluminescence (TL) and optically stimulated luminescence (OSL)] in aeolian deposits of the southern Duero basin (Díez Herrero et al., 2002). Deflation by similar winds blowing from the south-west formed many shallow depressions, now occupied by ponds and lakes on the plains and piedmonts of the northern Spanish Meseta during this period. Previous studies have invoked deflation to explain numerous Quaternary depressions in the Duero basin (Pérez-González, 1982; Pérez-González et al., 1994; Sanz Donaire and García Rodríguez, 1998). A friable substrate, such as that underlying the CL, would have been strongly affected by aeolian activity, creating the bowl-shaped depressions that are ubiquitous in the desertic areas (Bristow et al., 2009). However, the absence of sand dunes in the vicinity calls into question the role of wind in the evolution of the CL depression. 
The second important feature is the presence of a pavement of quartzite pebbles and cobbles, more strongly developed downwind in the north-western, northern and north-eastern shores of the lagoon (Figs. 2 and 7). Clasts show an inherited three-faceted pyramidal shape and are moderately to well-rounded, and free of muddy and sand matrix (clast-supported gravels). Gravel pavements are characteristic landforms of hot and arid regions (Cook and Warren, 1973; McFadden et al., 1987). Pavement formation has been attributed both to physical mechanisms, such as aeolian deflation and/or erosion (Cook and Warrern, 1973), chemical weathering of the clast source rocks (McFadden et al., 1987), or salt weathering, exploiting pre-existing weaknesses in the clasts or source rocks (AlFarraj et al., 2008). As discussed above, it is difficult to invoke development of a deflation pavement by the surface winnowing of fine-grained material. Similarly, an origin by erosion is unlikely, due to the low-energy littoral processes in this very shallow lake, and downslope movement of clasts is unlikely, given the low gradient of slopes connecting surrounding higher areas and the lacustrine depression.

Pavement genesis by chemical mechanisms, as proposed above, does not seem feasible, since the required set of conditions are not met in the CL. However, an alternative mechanism, i.e. chemical alteration (hydrolysis), which has been documented in the alteration zone underlying the alluvial piedmont where the CL is situated, could explain the loss of fine-grained material. It affects not only the more readily altered components such as 2:1 clays and feldspar, but even in quartz components within the dynamics of the shallow aquifer (Molina and Cantano, 2002; Molina, personal communication 2010). Bleaching and other processes are mainly related to the hydromorphic

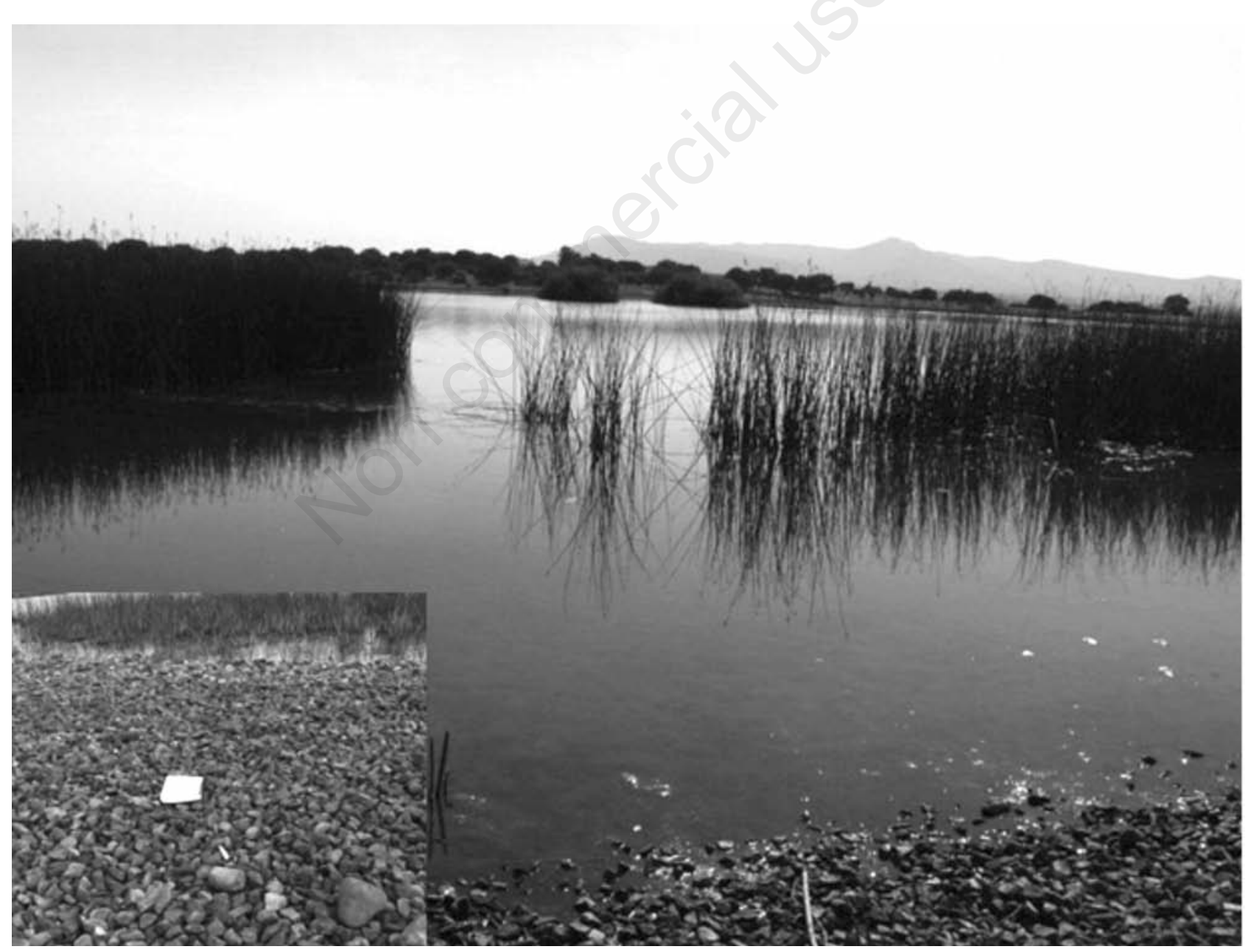

Fig. 7. The lagoon in autumn 2010, with the gravelly north-western shore in the foreground and the watershed drainage of the Paleozoic Tamames range in the background. The bottom left inset shows the appearance of the quartzitic gravels fringing the lake margin. Notebook for scale is $14 \times 21 \mathrm{~cm}$. 
conditions controlling the alteration profile overlying the siliciclastic formation, due to the poor external and internal (through pores) drainage in the semiconfined aquifer at the piedmont subsurface (Molina and Cantano, 2002; Molina et al., 2010; Molina Ballesteros et al., 2011). This process can be enhanced by the commonly high $\mathrm{pH}$ of the lagoon water, which would have accelerated dissolution of the fine-grained silicate sediments. When the water level falls, ferrolysis (oxidation of $\mathrm{Fe}^{2+}$ ) may occur, leading to increased acidity and hence to the release of cations from silicates, and the destruction of clays (Van Ranst and De Connick, 2002). The thinness of the accumulated muddy sediments originating at the shores of the lagoon may thus be attributed to the chemical loss of material. As a consequence, this process could aid in widening the lacustrine depression.

\section{CONCLUSIONS}

The absence of chemical precipitates, except during the drought periods, and minimal seasonal hydrochemical variation, characterise a hydrologically open through-flow system. Recharge is by underground flow from areas with higher piezometric potential within the surficial aquifer, and is controlled by the textural characteristics of the underlying Miocene formation.

The lagoon is normally a dilute lake (with around 150 mg L ${ }^{-1} \mathrm{TDS}$ ) dominated by $\mathrm{Na}^{+}, \mathrm{Ca}^{2+}, \mathrm{HCO}_{3}^{-}$and $\mathrm{Cl}^{-}$. During occasional droughts, there is a relative increase in the concentration of $\mathrm{SO}_{4}^{2-}, \mathrm{Cl}^{-}, \mathrm{Ca}^{2+}$ and $\mathrm{Mg}^{2+}$ ions that can exceed $500 \mathrm{mg} \mathrm{L}^{-1}$, rising as high as $1700 \mathrm{mg} \mathrm{L}^{-1}$ TDS.

During drier years, evaporation concentrates the chemical composition of the waters, photosynthetic activity is largely suppressed, and the decay of organic matter results in lower $\mathrm{pH}$ and, eventually, in the precipitation of gypsum. Calcite saturation was never achieved, in spite of the high $\mathrm{Ca}^{2+}$ content attained during the spring-summer period, because of the particular combination of $\mathrm{pH}$, $\mathrm{Ca}^{2+}$ concentration and $\mathrm{P}_{\mathrm{CO} 2}$. Stable isotopes indicate that DIC is the result of organic matter decay, while the sulphur in the sulphates is derived from oxidation of catchment-area sulphides with little isotope fractionation. The dilute water composition and the sulphur isotope characteristics indicate waters mainly derived from the weathering of metasedimentary and sedimentary siliceous rocks.

The evaporative trend of CL water produces an increase in all ions, and a decrease in $\mathrm{pH}$ by almost four units with respect to normal water levels, thus precluding the precipitation of calcite and favouring the precipitation of gypsum at some stages of brine concentration.

Development of the depression now occupied by the $\mathrm{CL}$ was initially controlled by tectonic faulting. Geomorphological and sedimentological features, GW flow and the loss of fine material by chemical weathering all con- tributed to modifying the initial depression, probably during the Holocene.

\section{ACKNOWLEDGMENTS}

Research for this work was financed by research projects SA075A04 (Consejería de Educación y Cultura, Junta de Castilla y León) and CGL2008-05584-C0201/BTE (Ministerio de Ciencia e Innovación). We thank Dr. J.J. Gómez-Alday and Dr. D.M. Deocampo for their help with PHREEQC calculations. We are grateful to Dr. E. Molina for discussions on the chemical mechanisms favouring material loss. Dr. Nicholas Edwards kindly helped improving the English version of the manuscript. Reviews by Dr. J.W. Magee and an anonymous reviewer greatly helped improve the manuscript. Comments by Dr. Magee were particularly useful in clarifying our ideas relative to the origin and evolution of the Cristo lagoon.

\section{REFERENCES}

Albaiges J, Algaba J, Arambarri P, Cabrera F, Baluja G, Hernández LMa, Castroviejo J, 1987. Budget of organic and inorganic pollutants in the Doñana national park (Spain). Sci. Total. Environ. 3:13-28.

Al-Farraj A, 2008. Desert pavement development on the lake shorelines of lake Eyre (South) South Australia. Geomorphology 100:154-163.

Alonso M, 1998. [Las lagunas de la España peninsular]. [Article in Spanish]. Limnética 15:1-176.

Alonso M, Comelles M, 1987. [Catálogo limnológico de las zonas húmedas esteparias de la cuenca del Duero]. [Book in Catalan]. Universidad de Barcelona, Barcelona: 452 pp.

Atekwana EA, Krishnamurthy V, 1998. Seasonal variations of dissolved inorganic carbon and $\mathrm{d} 13 \mathrm{C}$ of surface waters: application of a modified gas evolution technique. J. Hydrol. 205:265-278.

Bernáldez FG, Rey Benayas JM, Martínez A, 1993. Ecological impact of groundwater extraction on wetlands (Douro basin, Spain). J. Hydrol. 141:219-238.

Bernáldez G, 1989. [Ecosistemas áridos y endorreicos españoles], p. 223-238. In: Real Academia de Ciencias Exactas, Física y Naturales (ed.), [Seminarios sobre zonas áridas en España]. [Book in Spanish]. Real Academia de Ciencias Exactas, Física y Naturales.

Berner RA, Morse JW, 1974. Dissolution kinetics of calcium carbonate in seawater. IV. Theory of calcite dissolution. Am. J. Sci. 274:108-134.

Bristow CH, Drake N, Armitage S, 2009. Deflation in the dustiest place on earth: the Bodélé depression, Chad. Geomorphology 105:50-58.

Casado S, Montes C, 1995. [Guía de lagos y humedales de España]. [Book in Spanish]. J.M. Reyero ed., Madrid: 255 pp.

Castro A, Corretgé LG, de la Rosa JD, Fernández C, López S, García-Moreno O, Chacón E, 2003. The appinite-migmatite complex of Sanabria, NW Iberian massif, Spain. J. Petrol. 44:1309-1344.

Cirujano S, Velayo M, Castilla F, Gil M, 1992. [Criterios botánicos para la valoración de las lagunas y humedales españoles 
(Península Ibérica y las Islas Baleares)]. [Book in Spanish]. ICONA-CSIC ed., Madrid: 456 pp.

Coleman ML, Moore MP, 1978. Direct reduction of sulfates to sulfur dioxide for isotopic analysis. Anal. Chem. 50:15941595 .

Committee on Characterization of Wetlands, 1995. Wetlands, characterization: water, substrate and biota, p. 90-148. In: National Research Council (ed.), Wetlands, characteristics and boundaries. National Academy Press.

Cook RU, Warren A, 1973. Geomorphology in deserts. Batsford Publ., London: 322 pp.

Craig H, 1957. Isotopic standards for carbon and oxygen and correction factors for mass-spectrometric analysis of carbon dioxide. Geochim. Cosmochim. Ac. 12:133-149.

Deer WA, Howie RA, Zussman J, 1993. An introduction to the rock-forming minerals. $2^{\text {nd }}$ ed. Longman Scientific and Technical Publ., Harlow: 696 pp.

Deines P, 1980. The isotopic composition of reduced organic matter, p. 329-406. In: P. Fritz and J.Ch. Fontes (eds.), Handbook of environmental isotope geochemistry. 1. The terrestrial environment. Elsevier.

Deocampo DM, Ashley GM, 1999. Siliceous islands in a carbonate sea; modern and Pleistocene spring-fed wetlands in Ngorongoro Crater and Oldupai Gorge, Tanzania. J. Sediment. Res. 69:974-979.

Díez Herrero A, Bateman MD, López Sáez JA, Vegas Salamanca J, 2002. [Procesos eólicos tardiglaciares en la submeseta septentrional: cronología del manto arenoso de la Tierra de Pinares], p. 167-175. In: A. Pérez-González, J. Vegas and M.J. Machado (eds.), [Aportaciones a la geomorfología de España en el inicio del tercer milenio]. [Book in Spanish]. Instituto Geológico y Minero de España ed.

Drever JI, 1997. The geochemistry of natural waters. Surface and groundwater environments. $3^{\text {rd }}$ ed. Prentice Hall, Upper Saddle River: 436 pp.

Eugster HP, Hardie LA, 1978. Saline lakes, p. 237-293. In: A. Lerman (ed.), Lakes: chemistry, geology and physics. Springer-Verlag.

Fernández Aláez C, Fernández Aláez M, Trigal Domínguez C, Luis Santos B, 2006. Hydrochemistry of northwest Spain ponds and its relationships to groundwaters. Limnética 25:433-452.

Finlay JC, Kendall C, 2007. Stable isotope tracing of temporal and spatial variability in organic matter sources to freshwater ecosystems, p. 283-333. In: R. Michener and K. Lajtha (eds.), Stable isotopes in ecology and environmental science. Blackwell.

Fry B, Ruf W, Gest H, Hayes JM, 1988. Sulfur isotope effects associated with oxidation of sulfide by $\mathrm{O}_{2}$ in aqueous solution. Isot. Geosci. 73:205-210.

Garrels RM, Mackenzie FT, 1967. Origin of the chemical compositions of some springs and lakes, p. 222-242. In: R.F. Gould (ed.), Equilibrium concepts in natural water systems. American Chemical Society ed.

Given RK, Wilkinson BH, 1985. Kinetic control of morphology composition and mineralogy of abiotic sedimentary carbonates. J. Sediment. Petrol. 5:109-119.

Hardie LA, Eugster HP, 1970. The evolution of closed-basin brines. Min. Soc. Am. Spec. Pub. 3:273-290.

Hesse R, 1990. Origin of chert: diagenesis of biosiliceous sedi- ments, p. 227-252. In: I.A. McIlreath and D.V. Choquette (eds.), Diagenesis. Geological Association of Canada Publ.

Jones BF, Deocampo D, 2003. Geochemistry of saline lakes, p. 393-424. In: J.I. Drever, H.D. Holland and K.K. Turekian (eds.), Treatise on geochemistry. 5. Surface and ground water, weathering and soils. Elsevier-Pergamon.

Keil A, Berking J, Mügler I, Schütt B, Schwalb A, Steeb P, 2010. Hydrological and geomorphological basin and catchment characteristics of Lake Nam Co, South-Central Tibet. Quatern. Int. 218:118-130.

Kendall C, Doctor DH, 2003. Stable isotope applications in hydrologic studies, p. 319-364. In: J.I. Drever, H.D. Holland and K.K. Turekian (eds.), Treatise on geochemistry. 5. Surface and ground water, weathering and soils. Elsevier-Pergamon.

Lebron I, Suárez DL, 1996. Calcite nucleation and precipitation kinetics as affected by dissolved organic matter at $25^{\circ} \mathrm{C}$ and $\mathrm{pH}>$ 7.5. Geochim. Cosmochim. Ac. 60:2765-2776.

Li M, Kanga S, Zhua L, Youa Q, Zhanga Q, Wanga J, 2008. Mineralogy and geochemistry of the Holocene lacustrine sediments in Nam Co, Tibet. Quatern. Int. 187:105-116.

Martín-Serrano A, Cantano M, Carral P, Rubio F, Mediavilla R, 1998. [La degradación cuaternaria del piedemonte del río Yeltes (Salamanca)]. [Article in Spanish]. Cuaternario y Geomorfologia 12:5-17.

Martínez Graña AM, Goy JL, Zazo C, 2007. Analysis of water erosion using GIS and remote sensing for the management of protected natural environments on the south of the province of Salamanca (Spain), p. 84-85. In: J. Casalí and R. Giménez (eds.), Proc. IV Int. Symp. in gully erosion. Progress in gully erosion research. Pamplona, Spain, 17-19 September. Universidad Pública de Navarra ed.

McCrea JM, 1950. On the isotopic chemistry of carbonates and a paleotemperature scale. J. Chem. Phys. 18:849-857.

McFadden LD, Wells SG, Jercinovich MJ, 1987. Influences of eolian and pedogenic processes on the origin and evolution of desert pavements. Geology 15:504-508.

Molina E, Cantano M, 2002. Study of weathering processes developed on old piedmont surfaces in Western Spain: new contributions to the interpretation of the "Raña" profiles. Geomorphology 42:279-292.

Molina E, Cantano M, García Talegón J, 2010. Role of porosity in rock weathering processes: a theorical approach. Cadernos do Lab. Xeológico de Laxe 35:147-162.

Molina E, Cantano M, Vicente MA, García González, 1990. Some aspects of paleoweathering in the Iberian Hercynian Massif. Catena 17:333-346.

Molina Ballesteros E, García-Talegón J, Iñigo AC, Sánchez MG, Herrero Fernández H, 2011. Importance of porosity and transfer of matter in the rock weathering processes: two examples in central Spain. Environ. Earth. Sci. 64:1741-1754.

Nriagu JO, Rees CE, Mekhtiyeva VL, Lein AY, Fritz P, Drimmie RJ, Pankina RG, Robinson BW, Krouse HR, 1991. Hydrosphere, p. 177-266. In: H.R. Krouse and V.A. Grinenko (eds.), Stable isotopes. Natural and anthropogenic sulphur in the environment SCOPE 43. John Wiley \& Sons.

Pérez-González A, 1982. [El Cuaternario de la región central de la cuenca del Duero y sus principales rasgos geomorfológicos], p. 717-740. In: [Proc. 1a Reunión sobre la Geologia de la cuenca del Duero: Salamanca, 1979]. [Proc. in Spanish]. 
Servicio de Publicaciones Ministerio de Industria y Energia Publ.

Pérez-González A, Martín-Serrano A, Pol Méndez C, 1994. [Depresión del Duero], p. 351-388. In: M. Gutiérrez-Elorza (ed.), [Geomorfología de España]. [Book in Spanish]. Editorial Rueda.

Pierre C, 1988. Applications of stable isotope geochemistry to the study of evaporites, p. 300-344. In: B.Ch. Schreiber (ed.), Evaporites and hydrocarbons. Columbia University Press.

Quesada A, Sanchez-Maeso E, Fernández-Valiente E, 1995. Seasonal variations in the physical and chemical characteristics of a shallow water ecosystem, the rice fields of Valencia, Spain. Arch. Hydrobiol. 132:495-511.

Rey Benayas JM, 1990. [Ecosistemas de descarga de acuíferos en la cuenca del Duero]. [PhD Thesis in Spanish]. University of Madrid ed.. Madrid: 285 pp.

Rey Benayas JM, 1991. [Aguas subterráneas y ecología. Ecosistemas de descarga de acuíferos en Los Arenales]. [Book in Spanish]. Instituto Nacional para la Conservacion de la Naturaleza, Madrid: $141 \mathrm{pp}$.

Rey Benayas JM, Bernáldez FG, Levassor C, Peco B, 1990.
Vegetation of groundwater discharge sites in the Douro basin central Spain. J. Veg. Sci. 1:461-466.

Risacher F, Alonso H, Salazar C, 2002. Hydrochemistry of two adjacent acid saline lakes in the Andes of northern Chile. Chem. Geol. 187:39-57.

Robinson BW, Kusakabe M, 1975. Quantitative preparation of sulfur dioxide for ${ }^{34} \mathrm{~S} /{ }^{32} \mathrm{~S}$ analyses from sulfides by combustion with cuprous oxide. Anal. Chem. 47:1179-1181.

Sánchez y Llorente JM, Tomás Sánchez C, de Pablo Dávila F, 1997. [Consideraciones sobre el clima en Matacán (Salamanca)]. [Book in Spanish]. Caja Duero, Salamanca: 310 pp.

Sanz Donaire JJ, García Rodríguez MP, 1998. Aeolian origin of some wetlands in the Douro basin, the High Moraña region (Ávila, Spain). Observatorio medioambiental 1:65-93.

Toran L, Harris RF, 1989. Interpretation of sulfur and oxygen isotopes in biological and abiological sulfide oxidation. Geochim. Cosmochim. Ac. 53:2341-2348.

Van Ranst E, De Coninck F, 2002. Evaluation of ferrolysis in soil formation. Eur. J. Soil. Sci. 53:513-519. 